\title{
Antibacterial Activity of Punica granatum (Pomegranate) Fruit Peel Extract against Pathogenic and Drug Resistance Bacterial Strains
}

\author{
Alka Chaudhary ${ }^{1}$ and Siddarth Nandan Rahul ${ }^{2 *}$ \\ ${ }^{1}$ Department of Microbiology C.C.S. University Meerut- 250110, UP, India \\ ${ }^{2}$ Department of Biotechnology, Agriculture Sciences and Agricultural Informatics, Shobhit \\ University, Meerut- 250110, UP, India \\ *Corresponding author
}

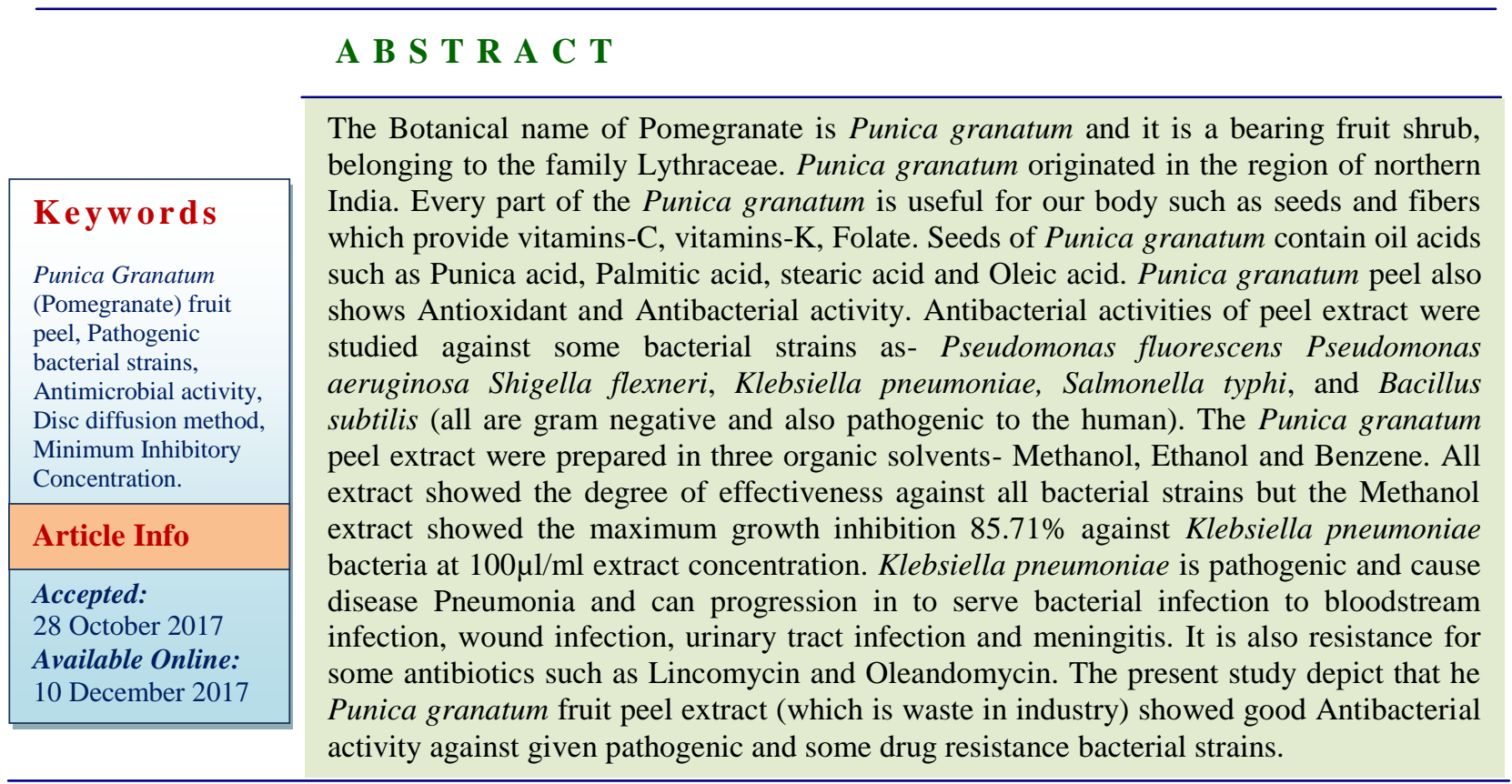

\section{Introduction}

Medicinal plants have always been a good source to find new remedies for human health problems. Recently a wide range of these plants have been screened for antimicrobial property (Martin and Ernst 2003, Upadhyay et al., 2010).

Punica granatum commonly called as Pomegranate, recently describe as nature power fruit, is a plant used in folkloric medicine for the treatment of various diseases
(Adbel moneim et al., 2011; Ajay kumar et al., 2005) widely cultivated in Mediterranean region. Pomegranate has strong antioxidant and anti-inflammatory properties recent studies have demonstrated its anticancer activity in several human cancers (Adhami and Mukhtar, 2007; Longtin, 2003). In addition pomegranate peel extract with an abundance of flavonoid and tannins has been show to have a high antioxidant activity (Abdel moneim et al., 2011). 
Pomegranate (Punica granatum L.) is the fruit of a tree belonging to the family Punicaceae. It is native from Iran to the Himalayas in northern India and has been cultivated and naturalized over the entire Mediterranean region since ancient times (Jurenka, 2008 and Meerts et al., 2009). The ripe fruit contains many arils separated by a white, membranous pericarp (Jurenka, 2008). Studies show that pomegranate juice (PJ) has potent antioxidant activity (ability to scavenge free radicals), significantly higher than more commonly consumed fruit juices such as grape, cranberry, grapefruit, and orange (Azadzoi et al., 2005; Basu 2009; Guet et al., 2008).

This activity has been attributed to antioxidant properties of polyphenols, including ellagitannins (hydrolyzable tannins) and anthocyanins (condensed tannins) (Cowan, 1999). Punicalagins are the major ellagitannins in the whole fruit and can be hydrolyzed to ellagic acid and other smaller polyphenols in vivo (Jurenka, 2008; Lansky, 2007). Pomegranate has been used in traditional medicine for the treatment of dysentery, diarrhea, helminthiasis, and respiratory pathologies (Lansky 2005Sánchez-Lamar, 2008). Currently there is considerable interest toward evaluating plant sources for alternative treatments against pathogenic bacteria which are now showing resistant to many drugs. Pomegranate (Punica granatum) peel is an inedible part obtained during processing of pomegranate juice which is completely waste in the industry. In the present investigation we have tested various extract of Punica granatum against pathogenic and drug resistant bacterial strains.

\section{Materials and Methods}

\section{Preparation of plant material}

The plant material (fruit part) was collected from the Cotton Research Station D.M. road
Bulandshahr region UP (India) during the starting of winter season. Collected plant material was clean up and crushed into powder form using pestle mortal.

\section{Extract preparation}

Fruit peel extract were prepared by immersing $1 \mathrm{gm}$ of powder in $5 \mathrm{ml}$ with four different organic solvents as Methanol, Ethanol and Benzene for 24 hours after filtration the extract were evaporated by the help of rotator evaporator. For stock solution each extract was re-dissolved with $5 \mathrm{ml}$ DMSO (dimethyl sulphoxide).

\section{Test microbial strains}

All tested bacterial strains viz., Pseudomonas aeruginosa (MTCC 162), Pseudomonas fluorescens (MTCC 254), Proteus vulgaris (MTCC 123), Bacillus subtilis (MTCC 251), Klebsiella pneumonia (MTCC 140), and Shigella flexneri (MTCC 182), Salmonella typhi (MTCC 326) were collected from MTCC (microbial type culture collection) IMTECH Chandigarh. These microorganisms were maintained on nutrient agar media (NAM) at $30^{\circ} \mathrm{C}$ for further investigation.

\section{Antibacterial screening}

The antimicrobial screening of the bacterial strains were carried out disc diffusion method (Grover and Moore 1962). The plant extracts of $0.1 \mathrm{ml}$ were mixed in $0.9 \mathrm{ml}$ of pre sterilized nutrient broth and then added $0.1 \mathrm{ml}$ bacterial culture suspension. In control sets, DMSO (in place of the plant extract) was used in the medium in appropriate amount. Culture tubes were incubated for 24 hours at $30^{\circ} \mathrm{C}$.

After incubation, sterile disc of $6 \mathrm{~mm}$ (Himedia) were dip in to the broth (treated as well as control separately), disc were 
aseptically inoculated on the agar surface of the nutrient agar medium in plates. Inoculated Petriplates were incubated at $30^{\circ} \mathrm{C}$ and the observations were recorded after 24 hours. Percentage of bacterial growth inhibition (BGI \%) was calculated per formula.

BGI $(\%)=\frac{\mathrm{dc}-\mathrm{dt}}{\mathrm{dc}} \times 100$

Where,

$\mathrm{dc}=$ diameter of control

$\mathrm{dt}=$ diameter of test

\section{Results and Discussion}

Some bacterial strains were drug resistance for some antibiotic viz., Klebsiella pneumoniae was resistance for many drugs as Lincomycin and Oleandomycin. Pseudomonas aeruginosa was resistance for many drugs as Tobramycin, Lincomycin and Oleandomycin (Table 1). The result of antibacterial activity of Pomegranate (Punica granatum) fruit peel was determined by disc diffusion method. All the extract of Pomegranate showed the antibacterial activity against all the pathogenic bacterial strains. The Methanol extract of Pomegranate fruit peel showed maximum growth inhibition $85.71 \%$ against Klebsiella pneumoniae and also showed minimum growth inhibition $10.29 \%$ against Bacillus subtilis. The Ethanol extract of Pomegranate fruit peel showed maximum growth inhibition $77.45 \%$ against Pseudomonas aeruginosa and also showed minimum growth inhibition $40.07 \%$ against Pseudomonas fluorescens. The Benzene extract of Pomegranate fruit peel showed maximum growth inhibition $82.35 \%$ against Pseudomonas aeruginosa and also showed minimum growth inhibition 55.93\% against Salmonella typhi (Table 2). The MIC value of Methanol extract against Klebsiella pneumoniae, in Ethanol extract against Pseudomonas aeruginosa, and in Benzene extract against Pseudomonas aeruginosa showed in Table 3.

Fig.1 Effect of different extracts on bacterial growth

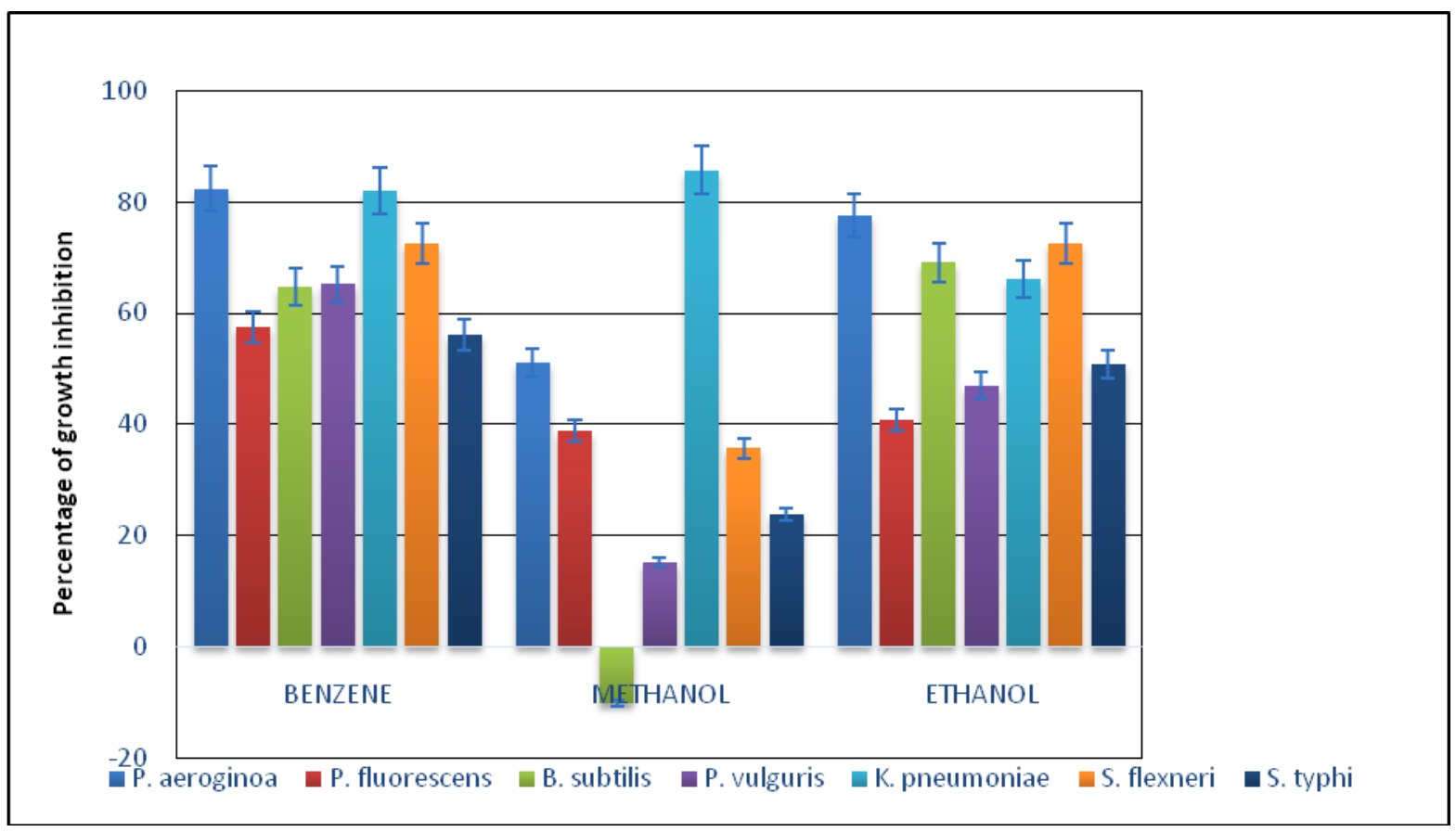


Table.1 Zone of inhibition by different drugs against bacterial strains

(Sahrawat and Shahi, 2013)

\begin{tabular}{|l|c|c|c|c|c|c|c|}
\hline Antibiotics & \multicolumn{7}{|c|}{ Zone of drug against bacterial strains (mm) } \\
\hline & $\begin{array}{c}\text { Proteus } \\
\text { vulgaris }\end{array}$ & $\begin{array}{c}\text { Pseudomonas } \\
\text { aeruginosa }\end{array}$ & $\begin{array}{c}\text { Pseudomonas } \\
\text { fluorescens }\end{array}$ & $\begin{array}{c}\text { Bacillus } \\
\text { subtilis }\end{array}$ & $\begin{array}{c}\text { Klebsiella } \\
\text { pneumoniae }\end{array}$ & $\begin{array}{c}\text { Shigella } \\
\text { flexneri }\end{array}$ & $\begin{array}{c}\text { Salmonella } \\
\text { typhi }\end{array}$ \\
\hline Tobramycin & 21 & - & - & 14.2 & 23 & 19.5 & 10.0 \\
\hline Cephaloridine & 17.5 & 12.02 & - & - & 14.5 & - & 8.50 \\
\hline Kanamycin & 22.5 & 10.0 & 11.5 & 15.6 & 12.5 & 16.5 & 7.50 \\
\hline Lincomycin & - & - & - & - & - & - & - \\
\hline Norfloxacin & 13 & - & - & 17.5 & 18.5 & 18.5 & 17.5 \\
\hline Oleandomycin & - & - & - & - & - & - & - \\
\hline
\end{tabular}

Table.2 Antibacterial screening of different extract of Pomegranate fruit peel against pathogenic and drug resistance bacterial strains by Disc diffusion method

\begin{tabular}{|l|c|c|c|}
\hline \multirow{2}{*}{ Pathogens } & \multicolumn{3}{|c|}{ Percentage of growth inhibition at 100 $\mathbf{\mu l} / \mathbf{m l}$} \\
\cline { 2 - 4 } & Methanol & Ethanol & Benzene \\
\hline Pseudomonas aeruginosa & $41.17 \%$ & $48.52 \%$ & $-32.03 \%$ \\
\hline Pseudomonas fluorescens & $1.85 \%$ & $25.92 \%$ & $40.74 \%$ \\
\hline Bacillus subtilis & $42.15 \%$ & $62.74 \%$ & $67.64 \%$ \\
\hline Proteus vulgaris & $25.07 \%$ & $0 \%$ & $-28.07 \%$ \\
\hline Klebsiella pneumoniae & $61.65 \%$ & $80.04 \%$ & $81.20 \%$ \\
\hline Bacillus subtilis & -10.09 & 69.11 & 64.70 \\
\hline Shigella flexneri & 35.63 & 72.41 & 72.41 \\
\hline
\end{tabular}

Table.3 Minimum inhibitory concentration of Pomegranate fruit peel against bacterial strains

\begin{tabular}{|l|c|c|c|}
\hline \multirow{2}{*}{ Bacterial strains } & \multicolumn{3}{|c|}{ MIC against pathogens in $\boldsymbol{\mu l} / \mathbf{m l}$} \\
\cline { 2 - 4 } & Methanol & Ethanol & Benzene \\
\hline Klebsiella pneumoniae & $1.56 \times 10^{-6}$ & - & - \\
\hline Pseudomonas aeruginosa & - & $12.5 \times 10^{-3}$ & - \\
\hline Pseudomonas aeruginosa & - & - & $6.25 \times 10^{-4}$ \\
\hline
\end{tabular}

As the present study on the antimicrobial activity of Pomegranate extract on the several human pathogenic bacteria (Fig. 1). The study shows that the various extract of Pomegranate can successfully control these kinds of bacteria as the other researchers have revealed that pomegranate peel is a rich source of tannins, flavonoids and other phenolic compounds (Li et al., 2006). Antioxidant and antibacterial properties of pomegranate peel in in-vitro model systems have been reported (Negi and Jayaprakasha, 2003; Reddy et al.,
2007; Opara et al., 2009; Alzoreky 2009). As the study says that Benzene extract of Pomegranate fruit peel can inhibit the population of both Pseudomonas aeruginosa and Salmonella typhi respectively which is already shown by many scientist like Lansky, 2005; Al-Zoreky, 2009; Gould et al., 2009; Machado et al., 2003; Opara et al., 2008 in their study which was on antimicrobial activity of pomegranate has been documented with different extracts and the potential therapeutic applications of the antimicrobial 
properties of pomegranate components have been investigated in human and murine models (Jurenka, 2008; Basu, 2009; Aviram et al., 2008; Betanzos et al., 2011; Sumner et al., 2005; Rock et al., 2008; Rosenblat et al., 2006; Shukla et al., 2008). However, FPJ antimicrobial activity has not been explored in spite of its high content of antioxidants.

Overall it can concluded that Pomegranate (Punica granatum L.) peel is a good source of antibacterial compounds against pathogenic and drug resistance bacterial strains and it can be use as drug against pathogens. The study reveals that different extraction with different solvents has antimicrobial activity and it should be further investigated.

\section{References}

Abdel MAE, Dkhil MA, AI-Quraishy S (2011) Studies on the effect of pomegranate (Punica granatum) juice and peel on liver and kidney in adult male rat. JMPR. In press.

Adhami VM, Mukhtr H (2007). Antioxident from green tea and pomegranate for chemoprevention of prostate cancer. Mol biotechnol. 37, 52-57.

Ajay kumar KB, Asheef M, Babu BH, Padikkala, $J(2005)$. The inhibition of gastric mucosal injuery by Punia granatum methanolic extract. J. Ethnopharmacol., 96, 171-176.

Alzoreky NS. Antimicrobial activity of pomegranate (Puncia granatum L) fruit peels. Int J Food Microbiol. 2009; 13: 24 28.

Al-Zoreky NS. Antimicrobial activity of pomegranate (Punica granatum L.) fruit peels. Int J Food Microbiol. 2009; 134: 244-8.

Aviram M, Volkova N, Coleman R, Dreher M, Reddy MK, Ferreira D, et al., Pomegranate phenolics from the peels, arils, and flowers are antiatherogenic: studies in vivo in atherosclerotic apolipoprotein e-deficient (E 0 ) mice and in vitro in cultured macrophages and lipoproteins. J Agric Food Chem. 2008; 56: $1148-57$.
Azadzoi KM, Schulman RN, Aviram M, Siroky MB. Oxidative stress in arteriogenic erectile dysfunction: prophylactic role of antioxidants. J Urol. 2005; 174: 386-93.

Basu A, Penugonda K. Pomegranate juice: a heart-healthy fruit juice. Nutr Rev. 2009; 67:49-56.

Betanzos-Cabrera G, Guerrero-Solano JA, Martínez-Pérez MM, Calderon-Ramos ZG, Belefant-Miller $\mathrm{H}$, Cancino-Diaz JC. Pomegranate juice increases levels of paraoxonase1 (PON1) expression and enzymatic activity in streptozotocin-induced diabetic mice fed with a high-fat diet. Food Res Int. 2011; 44: 1381-5.

Braga LC, Shupp JW, Cummings C, Jett M, Takahashi JA, Carmo LS, et al., Pomegranate extract inhibits Staphylococcus aureus growth and subsequent enterotoxin production. J Ethnopharmacol. 2005; 96: 3359.

Cowan MM. Plant products as antimicrobial agents. Clin Microbiol Rev. 1999; 12: 564-82.

Gould SWJ, Fielder MD, Kelly AF, Naughton DP. Anti-microbial activities of pomegranate rind extracts: enhancement by cupric sulphate against clinical isolates of $\mathrm{S}$. aureus, MRSA and PVL positive CAMSSA. BMC Complement Altern Med. 2009; 9: 23.

Grover, R.K. and Moore, J.D. 1962. Toximetric studies of fungicides against brown rot organism. Sclerotina fruticola. Phytopathology 52: 876-880.

Guo C, Wei J, Yang J, Xu J, Pang W, Jiang Y. Pomegranate juice is potentially better than apple juice in improving antioxidant function in elderly subjects. Nutr Res. 2008; 28: 72-7.

Jurenka JS. Therapeutic applications of pomegranate (Punica granatum L.): a review. Altern Med Rev. 2008; 13: 128-44.

Lansky EP, Newman RA. Punica granatum (pomegranate) and its potential for prevention and treatment of inflammation and cancer. J Ethnopharmacol. 2007; 109:177-206.

Li Y, Guo C, Yang J, Wei J, Xu J, Cheng S. Evaluation of antioxidant properties of pomegranate peel extract in comparison with pomegranate pulp extract. Food Chem. 
2006;

96:254-260.

Doi:

10.1016/j.foodchem.2005.02.033.

Machado TB, Pinto AV, Pinto MCFR, Leal ICR,

Silva MG, Amaral ACF, et al., In vitro activity of Brazilian medicinal plants, naturally occurring naphthoquinones and their analogues, against methicillin-resistant Staphylococcus aureus. Int J Antimicrob Agents. 2003; 21:279-84.

Martin KW, Earnst E. 2003 Herbal medicine for treatment of bacterial infection' a review of controlled clinical trials. $\mathrm{J}$ antimicrobes chemother 51, 241-6

Meerts IATM, Verspeek-Rip CM, Buskens CAF, Keizer HG, Bassaganya-Riera J, Jouni ZE, et al., Toxicological evaluation of pomegranate seed oil. Food Chem Toxicol. 2009; 47:1085-92.

Negi PS, Jayaprakasha GK. Antioxidant and antibacterial activities of Punica granatum peel extracts. J Food Sci. 2003; 68:14731477. doi: 10.1111/j.1365-2621.2003. tb09669.x.

Opara LU, Al-Ani MR, Al-Shuabi YS. Physicochemcial properties, vitamin $\mathrm{C}$ content and antimicrobial properties of pomegranate fruit (Punica granatum L) Food Bioprocess Tech. 2009; 2:315-321. doi: 10.1007/s 11947-008-0095-5.

Opara LU, Al-Ani MR, Al-Shuaibi YS. Physicochemical properties, vitamin $\mathrm{C}$ content, and antimicrobial properties of pomegranate fruit (Punica granatum L.) Food Bioprocess Technol. 2008; 2:315-21.

Reddy M, Gupta S, Jacob M, Khan S, Ferreir D. Antioxidant, antimalarial and antimicrobial activities of tannin-rich fractions, ellagitannins and phenolic acids from Punica granatum L. Planta Med. 2007; 73: 461-467. doi: 10.1055/s-2007-967167.
Rock W, Rosenblat M, Miller-Lotan R, Levy AP, Elias M, Aviram M. Consumption of Wonderful variety pomegranate juice and extract by diabetic patient's increases paraoxonase 1 association with high-density lipoprotein and stimulates its catalytic activities. J Agric Food Chem. 2008;56:870413.

Rosenblat M, Hayek T, Aviram M. Anti-oxidative effects of pomegranate juice (PJ) consumption by diabetic patients on serum and on macrophages. Atherosclerosis. 2006; 187:363-71.

Sahrawat, A. and Shahi M.P. 2013. Antibacterial screening of Sapindus mukorossi geartn fruit and Daucus carota L. root extract against pathogenic bacterial strains. Current discovery (2) 1. 76-80.

Sánchez-Lamar A, Fonseca G, Fuentes JL, Cozzi R, Cundari E, Fiore M, et al., Assessment of the genotoxic risk of Punica granatum L. (Punicaceae) whole fruit extracts. J Ethnopharmacol. 2008; 115:416-22.]

Shukla M, Gupta K, Rasheed Z, Khan KA, Haqqi TM. Consumption of hydrolyzable tanninsrich pomegranate extract suppresses inflammation and joint damage in rheumatoid arthritis. Nutrition. 2008; 24:733-43.

Sumner MD, Elliott-Eller M, Weidner G, Daubenmier JJ, Chew MH, Marlin R, et al., Effects of pomegranate juice consumption on myocardial perfusion in patients with coronary heart disease. Am J Cardiol. 2005; 96:810-14.

Upadhyay RK, Dwivedi P, Ahmad S. (2010) Screening of antibacterial activity of six plant essential oil against pathogenic bacterial strains. Asian J Med sci, 2:152-158

\section{How to cite this article:}

Alka Chaudhary and Siddarth Nandan Rahul. 2017. Antibacterial Activity of Punica granatum (Pomegranate) Fruit Peel Extract against Pathogenic and Drug Resistance Bacterial Strains. Int.J.Curr.Microbiol.App.Sci. 6(12): 3802-3807. doi: https://doi.org/10.20546/ijcmas.2017.612.437 